\title{
THE INFLUENCE OF FASHION CONSCIOUSNESS AND BRAND IMAGE ON PURCHASE DECISION: A SURVEY ON FEMALE CONSUMER AT HOUSE OF RIA MIRANDA
}

\author{
Devita Lusy Deasyana Rahma*, Sahara Afrianty \\ Faculty of Administrative Science, University of Brawijaya, Indonesia \\ *E-mail: lusyfiaub@gmail.com
}

\begin{abstract}
This study aims to analyze and test the influence brand image and fashion consciousness on product purchasing decisions. Data were collected by distributing questionnaire and analyzed through descriptive analysis, classical assumption test, multiple linear regression analysis, $F$ test and $t$ test. The results of multiple linear regression analysis indicate that variable of brand image partially has significant influence on the product purchase decision variable, by showing sig. $t(0.000)<\alpha(0.05)$, fashion consciousness has a significant partial effect on the product purchase decision by showing sig. $t(0.000)<\alpha(0.05)$, brand image and fashion consciousness have significant effect on the product purchasing decision with sig value. $F(0.000)<\alpha(0.05)$, and the probability significance $<0.05$ is 0.000 .
\end{abstract}

\section{KEY WORDS}

Brand image, fashion consciousness, product, purchase decision.

Currently the fashion industry, especially Islamic fashion in Indonesia, has been experiencing a huge market growth. In 2015, Indonesia has become the fifth largest Islamic fashion market in the world with a potential of USD 13.28 billion (Global Islamic Economy Report, 2017) with the average growth of the fashion industry of $10.17 \%$ annually (Euromonitor, 2018).

In addition, the development of the Internet and e-commerce industry also shows that the online marketing strategy is an increasingly important aspect for business to grow. In 2017, online trading in Indonesia stood at USD 7.056 billion, with the projected market growth above $20 \%$ annually in the next five years (Statista, 2017), with the most frequently purchased product profiles are fashion and accessories, which is $37.6 \%$ of total product transactions.

A good fashion brand image is indicated by to what extent the consumers are willing to pay extra money to get a certain brand, while at the same time, the other products with similar quality can be purchased at a cheaper price. As a result, profit margins of goods, especially fashion products, depend on the brand image. For this reason, it is important to manage the brand image value carefully over time (Peter et al, 2007).

Fashion industry in Indonesia has been growing rapidly, not only in domestic scale, Indonesia's fashion designers have also started reaching the international market. In general, the fashion industry is also considered to have been able to create employment for about 3.8 million people or $32 \%$ of the total workforce created from the creative economy. In addition, Indonesia is also a country with a majority Muslim population, that according to the population census in 2010 , there are about $87.18 \%$ of the $237,641,326$ people (source: Wikipedia); the majority Muslim population makes their adherents require to wear Muslim dresses as in Islam it is required for women as well as men to cover their private parts.

Referring to Thomson Reuters in the State of the Global Islamic Economic 2015, the value of spending by the world's Muslim societies was quite fantastic at around USD 230 billion for clothing in 2014 . That number represents $11 \%$ of the world's total clothing spending on average by $3.8 \%$ per year. It is estimated that the number may jump up to USD 322 billion in 2018, reaching about $11.5 \%$ of total global spending. Currently, the countries that become the export destination of Indonesian Muslim fashion are United States, Japan, Germany, Korea, United Kingdom, Australia, Canada, United Arab Emirates, Belgium and China. 
Table 1 - Consumer Countries of Indonesian Muslim fashion in 2014

\begin{tabular}{|l|l|l|}
\hline No & Countries & Sales \\
\hline 1. & Turkey & USD 24,84 billion \\
\hline 2. & United Arab Emirates & USD 18,24 billion \\
\hline 3. & Nigeria & USD 14,99 billion \\
\hline 4. & Saudi Arabia & USD 14,73 billion \\
\hline 5. & Indonesia & USD 12,69 billion \\
\hline 6. & Russia & USD 10,92 billion \\
\hline 7. & Egypt & USD 10,72 billion \\
\hline 8. & Pakistan & USD 10,52 billion \\
\hline
\end{tabular}

Source: Ministry of Trade of Republic of Indonesia (kemendag.go.id).

Based on Table 1 , Indonesia is in the $5^{\text {th }}$ position as the largest Muslim fashion consumer with a value of USD 12.69 billion in 2014. The data show the importance of developing Muslim fashion business in Indonesia has become the global benchmark for the Muslim fashion industry in the world. Amidst global market competitions, the contributors of the Muslim fashion industry should have strong and superior industry bases from bottom to the top levels. Chairman of Indonesia Fashion Chamber (IFC) Chapter Malang Agus Sunandar mentioned the competition of the fashion industry in Greater Malang region in East Java which has been increasing recently. There have been more fashion choices and alternatives in the City of Malang itself, making the people are concerned with the fashion in the region. According to Sunandar, people in the region now begin to look at several quality fashion products. He also said that the brand labelling by the prominent celebrities who sell their products directly in Malang region has been positive, especially for the fashion style of the community in Malang (malangtimes.com, 2017). Many fashion labels for hijabs, for example, the prominent national figures and celebrities are starting to open their outlets with their own brand labelling in smaller cities outside Greater Jakarta region. One of the labels which belong to celebrities that has opened in the City of Malang is Ria Miranda. Ria Miranda as a prominent figure has great contribution to the hijab fashion, including the trendsetter of the current hijab designers. Ria whose trademark "Riamiranda" is one of the prominent fashion designers whom are considered to influence the trend of Muslim clothing, it has been a hype among Muslim women in the country. Her designs are typically to exploit lines, touches of pastel color and girly feminine with strong characters, which are likely preferred by hijabers (nickname for Muslim women wearing modern and stylish hijabs) (Kompasiana, 2015).

\section{LITERATURE REVIEW} follows:

There are some factors forming the brand image described by Keller (2003: 167) as

1. Excellence of Brand Association (Favorability of Brand Association).

Profitable brand associations in which the consumers believe that the attributes and benefits provided by the brand should meet the needs and expectations of the consumers so that they may have positive attitude toward the brand (Keller, 2008: 58). Profitable associations are brands that are intended to satisfy the consumers' expectations and needs addressed in the form of convenient, secure, effective, efficient, and colorful products or services provided by the supportive marketing program. Keller describes the reputation of the brand can be assessed through the good or bad of the brand, likes or dislikes by the consumers in relation to the attributes and benefits of the brand. How important the brand association of the consumers' attitudes and decisions depends on desirability and deliverability.

2. Excellence of Brand Association (Uniqueness of Brand Association).

The essence of brand positioning is that the brand has the advantage of competing continuously or unique proposition that provides an exciting reason for consumers why they should buy the brand (Keller, 2008: 58). Therefore, a competitive advantage should be 
created that can be used as a reason for the consumers to choose a particular brand. Strong and union associations are critical to the success of a brand. Brand associations help to determine the scope of competition with other products and services (Keller, 2008: 58). Creating a unique impression shows a significant difference between other brands as a competitive value and makes the consumers interested in and choosing the brand. The goal of this strategy is to create a strong and unique association which is deeply embedded in the minds of the consumers.

3. Strength of Brand Association.

The strength of a brand association depends on how information instills into the consumer's memory and how the process persists as part of the brand image. When a consumer actively describes the information of a product or service, it will create an association that is getting stronger in the consumer's memory. The importance of brand associations in the consumer's memory depends on how the brand is considered; the deeper a person thinks about the information of a brand and relates it to their previous knowledge, the stronger the brand association it has. The power of brand association is influenced by two factors: relevancy to the consumer and the consistency seen by the consumer over time.

Consumers form beliefs about brand attributes and benefits in various ways. Brand attributes are descriptive features that characterize a product or service (Keller, 2008: 57). Brand benefits are the personal value attached to the attributes of the product or service and what the product or service can deliver to the consumers. The power of brand associations is made up of word of mouth (friends, family, colleagues, etc.) or other non-commercial information sources. These associations are derived from information that consumers can get from brand attributes and brand benefits.

- $\mathrm{H} 1$ : Brand image variable (X1) has partially significant effect on product purchase decision $(\mathrm{Y})$;

- H2: Fashion consciousness variable (X2) partially has significant effect on the product purchase decision (Y);

- H3: Brand image and fashion consciousness simultaneously have significant effect on the product purchase decision $(\mathrm{Y})$.

According to Nam et al., (2007), someone's fashion consciousness refers to the level of their involvement in style or dress mode. O'Cass and Siahtiri (2013) define fashion-conscious consumers as people who are deeply involved with everything about fashion. Fashion consciousness depicts someone's consciousness of fashion and ability to choose, dress equally or imitate and be responsive to fashion (Milewski, 2005). According to Wan, Youn, and Fang (2007), many studies have explained that fashion consciousness is a significant construction that defines loyal consumers who are aware of their physical image and appeal.

The decision to purchase a product is a collection of decisions. The buying decision has four structural components as mentioned by Swastha and Handoko (2013: 102) as follows:

1. Decisions about the type of product. The consumers make a decision to buy a product or use the money for other purposes.

2. Decisions about product form. The consumers can take a decision to buy products with a particular form. The decision might concern with the pattern of size, quality, style, and so forth.

3. Decisions about the brand. The customers have to make a decision about which brand to buy. Each brand has its own differences. In this case the company should know how the consumers choose the brand.

4. Decisions about the seller. Consumers have to make decisions on where the radio will be purchased, whether at a department store, an electrical equipment store, a radio specialty store, or another store. In this case, producers, wholesalers and retailers need to know how consumers choose a particular seller.

5. Decisions on the number of products. The consumers make decisions about how many products to buy at a time. The number they buy may be more than one unit.

6. Decision about the time of purchase. Consumers can take a decision about when to make a purchase. This problem will involve the availability of money to buy a radio. 
Therefore, the company should know the factors that influence the consumer's decision in determining the time of purchase. Thus the company may manage the time of production and marketing activities.

7. Decision on payment method. The consumer should make a decision about the payment method of the purchased product, whether by cash or by installment.

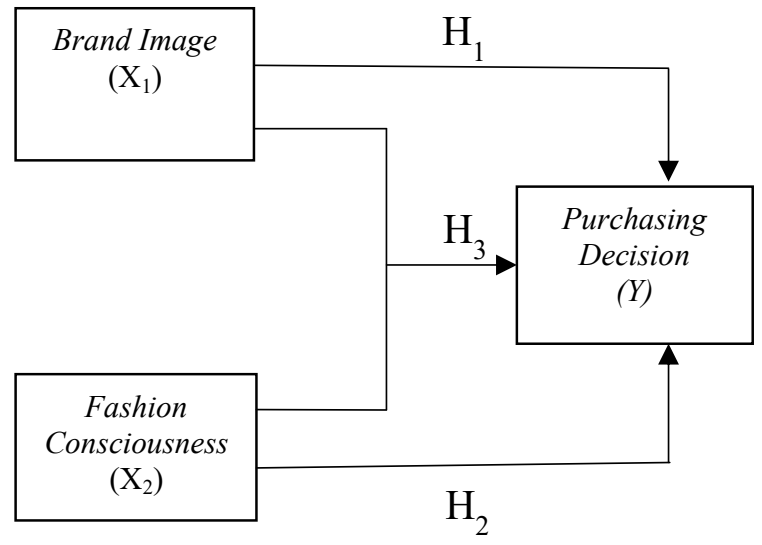

Figure 1 - Model of Hypotheses

\section{METHODS OF RESEARCH}

This is an explanatory research with non-probability sampling determined through accidental sampling technique. Total respondents were 100 women customers who bought at House of Ria Miranda, Malang, Indonesia. The location of this study was chosen because it is closely related to the topic raised by researchers in conducting this research.

\section{RESULTS AND DISCUSSION}

The results of this study indicate that brand image variable (X1) partially has positive and significant effect on purchase decision upon the products $(Y)$. The grand mean value obtained for brand image variable of 4.26 indicated that the response from the respondents was very high.

The results of this study also prove the opinions from the experts who claim that the brand image has an influence on purchasing decisions. In relation with the brand image, according to Schiffman, Kanuk (2008), purchasing decision is as a close relationship that occurs the selection of two or more alternatives purchasing decision choices, and brand image means that a person can make decisions that there must be some alternative options. The decision to buy may lead to how the process in making that decision is done.

Table 2 - Results of Multiple Linear Regression Analysis

Coefficients $^{a}$

\begin{tabular}{|c|c|c|c|c|c|c|c|}
\hline \multirow{2}{*}{\multicolumn{2}{|c|}{ Model }} & \multicolumn{2}{|c|}{ Unstandardized Coefficients } & \multirow{2}{*}{$\begin{array}{c}\text { Standardized Coefficients } \\
\text { Beta }\end{array}$} & \multirow{2}{*}{$\mathrm{t}$} & \multirow{2}{*}{ Sig } & \multirow{2}{*}{$\begin{array}{c}\text { Correlations } \\
\text { Zero-order } \\
\end{array}$} \\
\hline & & $\mathrm{B}$ & Std. Error & & & & \\
\hline \multirow{3}{*}{1} & (Constant) & 6.543 & 2.248 & & 2.910 & .004 & \\
\hline & Brand Image & .229 & .055 & .404 & 4.174 & .000 & .746 \\
\hline & Fashion Consciousness & .171 & .037 & .442 & 4.572 & .000 & .755 \\
\hline
\end{tabular}

In addition, the relationship of brand image can be formed due to factors such as attractiveness and also similarity or personal resemblance. This is in line with the factors why consumers make purchasing decisions, namely the results of alternative evaluations of different available brands to be used as a reference in the decision-making process. 
Table 3 - Model Summary

\begin{tabular}{|c|c|c|c|c|}
\hline Model & $\mathrm{R}$ & $\mathrm{R}$ Square & Adjusted R Square & Std. Error of the Estimate \\
\hline 1 & $.797^{\mathrm{a}}$ & .636 & .628 & 2.785 \\
\hline \multicolumn{2}{|l}{} \\
\hline
\end{tabular}

The results of this study indicate that the fashion consciousness variable (X2) partially has positive and significant effect on purchase decision to buy products $(Y)$. The grand mean value obtained for the fashion consciousness variable was 3.94 , indicating that the responses of the respondents were high.

The results of this study were similar with research conducted by Hassan and Harun (2016) that the results showed that any changes of style, fashion motivation, fashion uniqueness and the source of fashion knowledge are influential towards fashion consciousness. The practical implications of the results of this study may provide insight to people involved in the fashion industry such as designers, retailers and marketers, to understand the market segment, namely the hijabers.

The results of this study indicate that brand image (X1) and fashion consciousness (X2) variables together have significant effect on product purchase decision variable $(Y)$, which was indicated by significant value of $F$ equal to $0.000(\alpha<0.05)$ so that $H_{0}$ is rejected and $\mathrm{H} 1$ is accepted. Based on the analysis of the coefficient of determination in Table 4.11, it was obtained the adjusted results of $\mathrm{R}$ square 0.628 or $62.8 \%$ which means that $62.8 \%$ of product purchase decision is affected by independent variables of brand image (X1) and fashion consciousness $(\mathrm{X} 2)$, while $37.2 \%$ of product purchase decision variable $(\mathrm{Y})$ is influenced by other variables.

In addition to the coefficient of determination, it was also obtained the correlation coefficient which has a value of $R$ (correlation coefficient) of 0.797 , indicating that the relationship between independent variables of brand image (X1) and fashion consciousness (X2) with the dependent variable of product purchase decision $(Y)$ is strong because it is in the interval of $0.600-0.799$.

\section{CONCLUSION}

The research results may lead to several conclusions as follows:

- To determine the partial influence of independent variables of brand image (X1) and fashion consciousness ( $\mathrm{X} 2$ ) towards product purchase decision $(\mathrm{Y})$, the test was conducted. Based on the test results, it was found that there were two variables that have significant influence on the decision to buy products $(Y)$, brand image $(\mathrm{X} 1)$ and fashion consciousness (X2).

- Based on the test results, it was found that the fashion consciousness variable (X2) has the largest statistical value of effect. So that the fashion consciousness (X2) variable has the strongest influence compared to other variables, and it has dominant influence to the product purchasing decision $(\mathrm{Y})$.

- The simultaneous influence of each independent variable on product purchase decision ( $\mathrm{Y}$ ) was done by testing. From the results of multiple linear regression analyses, it was obtained that the independent variables have significant influence simultaneously on the product purchase decision $(\mathrm{Y})$, so it can be concluded that the test against the hypothesis that the simultaneous effect of independent variables on the product purchase decision $(\mathrm{Y})$ is acceptable.

\section{REFERENCES}

1. Hassan, H.S. \& Harun, H. 2016. Factors Influencing Fashion Consciousness in Hijab Fashion Consumption Among Hijabistas. Journal of Islamic Marketing. Vol.7(4): 476-494.

2. Keller, K.L. 2003, Strategic Brand Manajemen, Second Edition, Prentice Hall. Translated by B/ Sabran. Jakarta: Penerbit Erlangga. 
3. Kotler, P. \& Keller, K.L. 2008. Manajemen Pemasaran. Translated by B. Sabran. Jakarta: Penerbit Erlangga.

4. Milewski, J.A. 2005. Fashion and The Culture of Consumption Perceptions of Fashion Trends Among College Students. Paper presented at the Annual Meeting of The American Sociological Association, Marriot Hotel, Loews Philadelphia, PA

5. Nam, J., Hamlin, R., Gam, H.J., Kang, J.H., Kim, J., Kumphai, P., Starr, C., \& Richards, L. 2007. The Fashion-conscious Behaviours of Mature. International Journal of Consumers Studies, 31(1):102-108.

6. O'cass, A., Lee, W.J, \& Siahtiri, V. 2013. Can Islam and Status Consumption Live Together in The House of Fashion Clothing. Journal of Fashion Marketing and Management, 17(4):pp. 440-459.

7. Peter, J.P. \& Donnelly Jr, J.H. 2007. Marketing Management Knowledge and Skills Eight Edition, New York: McGraw-Hill//rwin

8. Schiffman, L. \& Kanuk, L.L. 2008. Perilaku Konsumen. Jakarta: PT Indeks.

9. Swastha, B. \& Handoko, H.T. 2013. Manajemen Pemasaran Analisis Perilaku Konsumen. Yogyakarta. BPFE.

10. Wan, F., Youn, S., \& Fang, T. 2007. Passionate Surfers in Image-driven Consumer Culture: Fashion Consciousness, appearance savvy people and their way of life, Advances in Consumer Research, 28(1):266-274. 